\title{
Haematology and biochemical parameters of different feeding behaviour of teleost fishes from Vellar estuary, India
}

\author{
P. Satheeshkumar • G. Ananthan • D. Senthil Kumar • \\ L. Jagadeesan
}

Received: 7 December 2010 / Accepted: 7 April 2011

(C) Springer-Verlag London Limited 2011

\begin{abstract}
Haematological parameters have been recognized as valuable tools for monitoring fish health. Haematological and serum biochemical parameters were studied and compared different feeding behaviour of teleost fishes. Three marine teleost fishes, Lates calcarifer (carnivores), Mugil cephalus (omnivores) and Chanos chanos (herbivores), were carried out in order to find out a normal range of blood parameters which would serve as baseline data for assessment of the health status of the fish as well as reference point for future comparative surveys. Blood parameters such as red blood cell count (RBC) and white blood cells count (WBC), haemoglobin, haematocrit, mean cell haemoglobin concentration (MCHC), mean cell volume (MCV), mean cell haemoglobin, glucose, protein, cholesterol and urea were estimated from teleost fishes of different trophic level. Statistical analysis revealed that differences in haematological parameters between marine fish were significant $(P<0.01)$. The result revealed that haematological $\mathrm{RBC} / \mathrm{WBC}$ ratio, $\mathrm{MCV}$ and $\mathrm{MCHC}$ were significantly correlated at $P<0.05$ level. The $\mathrm{RBC} / \mathrm{WBC}$ level increased due to the decrease in $\mathrm{WBC}$ during the
\end{abstract}

P. Satheeshkumar $(\varangle) \cdot$ G. Ananthan $\cdot$ L. Jagadeesan

Faculty of Marine Science,

Centre of Advanced Study in Marine Biology,

Annamalai University,

Parangipettai, Tamilnadu 608502, India

e-mail: revathysathish86@gmail.com

P. Satheeshkumar

Central Marine Fisheries Research Institute,

Kochi, Kerala 682018, India

D. S. Kumar

Department of Zoology,

Kandaswamy Kandar Arts and Science College,

Paramathy-Velur, Tamilnadu 638181, India study. Blood serum biochemical parameters can be used for confirming the maturity and monitoring any changes in the quality of waters and related soils.

Keywords Blood · Fish · Haematology · Erythrocyte · Serum biochemistry

\section{Introduction}

Knowledge of the haematological characteristics is an important tool that can be used as an effective and sensitive index to monitor physiological and pathological changes in fishes. Normal ranges for various blood parameters in fish have been established by different investigators in fish physiology and pathology (Rambhaskar and Srinivasa Rao 1986; Xiaoyun et al. 2009). The analysis of blood indices has proven to be a valuable approach for analysing the health status of farmed animals as these indices provide reliable information on metabolic disorders, deficiencies and chronic stress status before they are present in a clinical setting (Bahmani et al. 2001). Blood biochemistry parameters can be also used to detect the health of fish (De Pedro et al. 2005). Exogenous factors, such as management (Svobodova et al. 2008), diseases (Chen et al. 2005) and stress (Cnaani et al. 2004), always induce major changes in blood composition. For example, significant fluctuations were detected in the concentrations of cortisol, glucose, cholesterol and other basic components in response to handling and hypoxic stress (Skjervold et al. 2001). The levels of cortisol and glucose are considered to be specific indicators of sympathetic activation during stress conditions (Lermen et al. 2004). Basic ecological factors, such as feeding regime and stocking density, also have a direct influence on certain biochemistry parameters (Coz-Rakovac 
Table 1 Physico-chemical factors of the study site

\begin{tabular}{lrr}
\hline & Mean \pm SD & Range \\
\hline Temperature $\left({ }^{\circ} \mathrm{C}\right)$ & $31.83 \pm 3.5$ & $27.0-36.5$ \\
Salinity $(\mathrm{ppt})$ & $26.16 \pm 12.0$ & $3.14-35.8$ \\
DO $(\mathrm{mg} / \mathrm{l})$ & $4.48 \pm 0.53$ & $3.93-5.41$ \\
$\mathrm{pH}$ & $7.80 \pm 0.43$ & $7.12-8.31$ \\
\hline
\end{tabular}

$D O$ dissolved oxygen

et al. 2005). To date, however, data reported in the literature refer mainly to acute stress status in different farmed fish species and there have been an insufficient number of studies on the comparative haematological differences between different feeding behaviour of fish that share the same ecological zone. This present study would form a baseline data for assessment of health status of the fish as well as reference point for future comparative study effects of different feeding behaviour of fishes.

\section{Materials and methods}

\section{Sampling}

Healthy marine teleost fishes were collected from Vellar estuary (lat. $11^{\circ} 29 \mathrm{~N}$ and $79^{\circ} 46 \mathrm{E}$ ), Parangipettai of southeast coast of Tamilnadu, India. The estuary is seasonally bar-built and semi-diurnal type flows eastwards and empties into the Bay of Bengal at Parangipettai on southeast coast of India, carrying the wastes from the adjacent agriculture lands and industries in addition to domestic municipal and distillery effluents. Fish samples were collected from 2007 to 2008. From the collection site, the water quality dissolved oxygen was estimated by Winkler's methods (Strickland and Parsons 1972), salinity by an Erma hand refractometer (Tokyo). The $\mathrm{pH}$ and water temperature were measured by using $\mathrm{pH}$ tester pen (Japan) and thermometer, respectively.
Haematology and biochemical analysis

A total of three species of marine teleost fishes namely Lates calcarifer (carnivores), Mugil cephalus (omnivores) and Chanos chanos (herbivores) were collected and acclimated in large fibreglass tanks. Fishes ranged from 235 to $410 \mathrm{~g}$ in weight and 25 to $30 \mathrm{~cm}$ in body length. Twenty-five fishes from each species were selected for this study. Blood was collected by direct heart puncturing using sterile disposable plastic syringe with a 22-gauge needle (Molnar 1960). Heparine sodium (1\%) was used as an anticoagulant (Svobodova et al. 2008). The collected blood samples were immediately subjected to haematological analysis. The blood was diluted with appropriated diluting fluids for RBC and WBC counts were determined using improved Neubauer haemocytometer and calculated (Blaxhall and Daisley 1973). Replicated counts were made for each blood samples. Sahli's haemoglobinometer was used to estimate haemoglobin (HB) percentage $(\mathrm{HB} \%)$. Haematocrit $(\mathrm{HCT})$ was determined using micro haematocrit capillaries filled with blood and centrifuged at $8,700 \times g$ for $5 \mathrm{~min}$ and expressed as percentage of total blood volume (Wintrobe 1974). Mean corpuscular volume (MCV), mean cell haemoglobin $(\mathrm{MCH})$ and mean cell haemoglobin concentration $(\mathrm{MCHC})$ were calculated from the average values of $\mathrm{HB} \%$ (Dacie and Lewis 1984). For the determination of erythrocyte sedimentation rate (ESR), the blood was mixed well and $200 \mathrm{~mm}$ was drawn into a Westurgen tube. The tubes were placed vertically and were left undisturbed for $60 \mathrm{~min}$; after that, the level of the column of sediment was noted as ESR. Biochemical estimation of blood glucose, blood protein, blood cholesterol and blood urea were determined by following standard methods (Folin and Wu 1920; Annino 1976; Henry 1968; Fawcette and Scott 1960).

\section{Statistical study}

Differences in haematological parameters between the three marine fish were statistically analysed by two-way
Table 2 Haematological parameters of marine teleost fishes $($ mean \pm SD)

$* P<0.01$ (significance)

$R B C$ red blood cell count, $W B C$ white blood cells count, ESR erythrocyte sedimentation rate, $M C V$ mean cell volume, $M C H$ mean cell haemoglobin, $M C H C$ mean cell haemoglobin concentration

\begin{tabular}{lcccc}
\hline Parameters & L. calcarifer & M. cephalus & C. chanos & $P$ value \\
\hline RBC $\left(\times 10^{6} \mu \mathrm{l}\right)$ & $2.96 \pm 0.25$ & $2.52 \pm 0.21$ & $2.6 \pm 0.51$ & $<0.01^{*}$ \\
WBC $\left(\times 10^{3} \mu \mathrm{l}\right)$ & $21.6 \pm 1.45$ & $28.6 \pm 1.02$ & $26.33 \pm 1.56$ & $<0.01^{*}$ \\
RBC/WBC (\%) & $0.107 \pm 0.001$ & $0.082 \pm 0.01$ & $0.085 \pm 0.00$ & $<0.01^{*}$ \\
Haemoglobin (\%) & $53.23 \pm 2.35$ & $37.6 \pm 1.42$ & $52.33 \pm 1.72$ & $<0.01^{*}$ \\
Haematocrit (\%) & $44.33 \pm 1.32$ & $28.66 \pm 1.02$ & $43.66 \pm 3.23$ & $<0.01^{*}$ \\
ESR & $0.5 \pm 0.03$ & $0.43 \pm 0.01$ & $0.56 \pm 0.02$ & $<0.01^{*}$ \\
MCV (\%) & $13.38 \pm 2.34$ & $11.37 \pm 1.0$ & $16.81 \pm 3.1$ & $<0.01^{*}$ \\
MCH (\%) & $156.55 \pm 5.45$ & $149.4 \pm 3.78$ & $201.26 \pm 11.4$ & $<0.01^{*}$ \\
MCHC (\%) & $120.07 \pm 9.45$ & $131.86 \pm 7.65$ & $119.85 \pm 12.02$ & $<0.01^{*}$ \\
\hline
\end{tabular}


Table 3 Blood serum biochemical parameters of marine teleost fishes $($ mean $\pm \mathrm{SD})$

${ }^{*} P<0.01$ (significance)

\begin{tabular}{lcrrr}
\hline Parameters & L. calcarifer & M. cephalus & C. chanos & P value \\
\hline Glucose $(\mathrm{mg} / \mathrm{dl})$ & $64.29 \pm 2.5$ & $90.06 \pm 3.6$ & $81.06 \pm 5.02$ & $<0.01^{*}$ \\
Protein $(\mathrm{mg} / \mathrm{dl})$ & $4.77 \pm 0.95$ & $4.2 \pm 0.65$ & $4.36 \pm 0.25$ & $<0.01^{*}$ \\
Cholesterol $(\mathrm{mg} / \mathrm{dl})$ & $291.69 \pm 10.2$ & $208.04 \pm 2.01$ & $253.16 \pm 8.25$ & $<0.01^{*}$ \\
Urea $(\mathrm{mg} / \mathrm{dl})$ & $4.56 \pm 1.3$ & $6.53 \pm 3.21$ & $5.56 \pm 0.65$ & $<0.01^{*}$ \\
\hline
\end{tabular}

analysis of variance without replication. All these statistical analyses were performed using the SPSS statistical software (Version 7.5 for Windows XP, SPSS, and Chicago, IL, USA). Bray-Curtis similarity and multidimensional scale plot were performed using PAST statistical (Version 1.93 for Windows $\mathrm{XP)}$.

\section{Results and discussion}

Table 1 shows the physico-chemical parameters of water obtained from Vellar estuary. The water temperature (31.83 \pm 3.5 ) ranged from $27^{\circ} \mathrm{C}$ to $36.5^{\circ} \mathrm{C}$, and salinity level (26.16 \pm 12.0$)$ varied from 3.14 to 35.8 ppt. $\mathrm{pH}$ fluctuated monthly $(7.80 \pm 0.43)$ and varied from 7.12 to 8.31 . Dissolved oxygen concentration (4.48 \pm 0.53$)$ ranged from 3.93 to5.41 mg/l. Haematological and biochemical values of three marine teleost fishes are given in Tables 2 and 3. Definite variations between the species were detected in all haematological and biochemical values. High level of RBC was recorded in L. calcarifer, followed by M. cephalus and C. chanos. In addition RBC count in the fishes was significantly higher $(P<0.01)$. The high erythrocyte number was associated with fast movement, predaceous nature and high activity, with streamlined body (Rambhaskar and Srinivasa Rao 1986). However, significant differences in the values of erythrocyte volumes between the groups were observed in this study, suggesting that in the intensive estuary environments, the elevated RBC counts and $\mathrm{HB}$ concentration are a response to the higher metabolic demand and have no impact on erythrocyte volume. The increased number of RBC indicates oxygen demand in the tropical region to meet the higher oxygen requirement at higher metabolic rates (Engel and Davis 1964). Maximum HB was recorded in $L$. calcarifer and C. chanos, least value was recorded in M. cephalus. HB value in the present study was within the range $37.6-53.23 \%$; low haemoglobin value was associated with the low active fishes. Similar results were already reported by Rambhaskar and Srinivasa Rao (1986). RBC and HB concentration tend to increase with length and age of the fishes (Das 1965). HCT value showed a polynomial relationship, quadratic regression to the different to the length of the fish $[\mathrm{Ht}=-8.33(\operatorname{Ln}(x)+$ 57.003; $R 2=0.3931), P<0.01]$. Blaxhall and Daisley (1973) have reported the possibility of using HCT as a tool in the aquaculture and fishery management for checking the anaemic condition. HCT value in the present study was within the range 28.66-44.33\%; fish HCT values were usually between $20 \%$ and $35 \%$ and rarely attain greater than $50 \%$ (Clark et al. 1976). RBC/WBC ratio, MCV, MCHC and cholesterol was significantly correlated at $P<0.05$ level. This may be due to the overall oxygen consumption

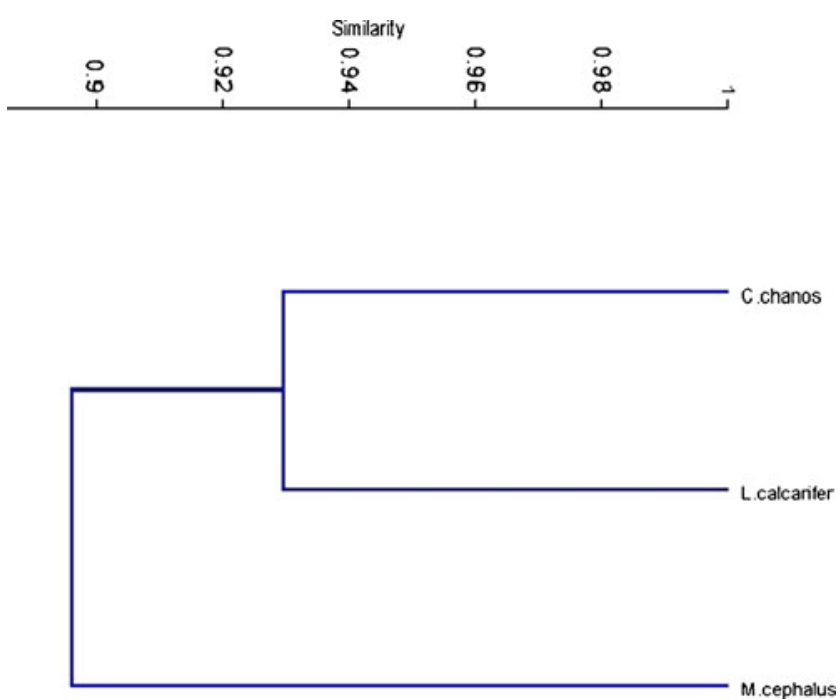

Fig. 1 Cluster analyses between the marine teleost fishes

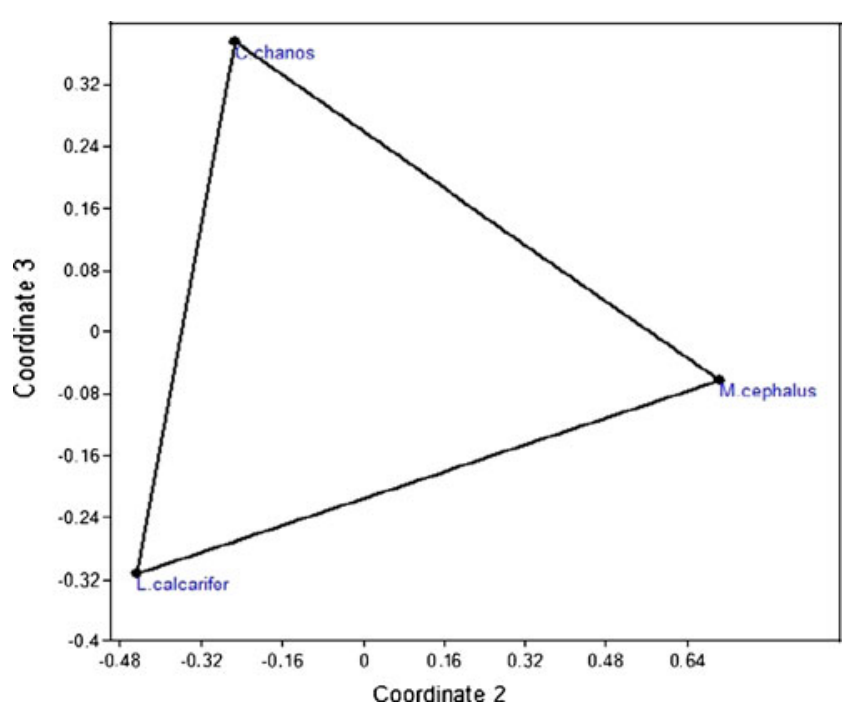

Fig. 2 Multidimensional scale plots between the marine teleost fishes 
rates and swimming performance under normal condition (Stillwell and Benfey 1995). The RBC/WBC level increased due to the decrease of WBC during this study. The high leucocyte volume was recorded in M. cephalus, C. chanos and $L$. calcarifer. There is an inverse relationship between $\mathrm{WBC}$ and RBC count observed in all the three fishes of the present investigation. High RBC count perhaps lessens the requirement for large number of WBC (Xiaoyun et al. 2009). An increased ESR level was recorded in L. calcarifer, $C$. chanos and lowest in M. cephalus. The ESR level may be a consequence of alternation in blood plasma of different fish species or may be due to the stress condition (Joseph John 2007)

Blood biochemical parameters with significant variations $(P<0.01)$ were observed for the concentrations of glucose, protein, cholesterol and urea. The ranges of serum biochemistry vary from species to species and can be influenced by many biotic and abiotic factors such as water temperature, seasonal pattern, food, age and sex of the fish (Jawad et al. 2004). An increased blood glucose and protein level was recorded in $L$. calcarifer, this may probably be due to an increased depletion of liver glycogen (Ojolick et al. 1995). Our findings confirm those of Coz-Rakovac et al. (2005) who reported a significantly elevated glucose level in farmed Dicentrarchus labrax as compared to the wild ecosystem. Strange (1980) also reported that blood glucose level may decrease with increasing water temperature in channel catfish. Blood glucose level may vary according to season and water temperature, and glucose concentration in fish decreases with age and size (Coz-Rakovac et al. 2005). The increased plasma protein concentration can be caused by structural liver alternations that reduce aminotransferase activity, with concurrent reduction in deamination capacity (Kavadias et al. 2004). Hrubec et al. (2001) stated that protein level in striped bass increased with age. Cholesterol concentration of $L$. calcarifer was higher due to high proportion of fat in the chemical composition of their food. Hill (1982) reported that cholesterol concentrations increase as the fish size increased. Bano (1985) observed an increase in the serum cholesterol level after administration of pesticides. A high blood urea concentration recorded in M. cephalus is likely to be a sign of stress associated with the increase in the cortisol level (Borges et al. 2007).

Bray-Curtis similarities were calculated (root transformed) between three species, and the resulting dendrogram is shown in (Fig. 1). Two distinct fish community groupings could be distinguished that apparently reflected differences in haematological/habitat types within the fish group. The carnivore fish $L$. calcarifer and herbivore fish C. chanos were one distinct community group; M. cephalus was generating independently and makes one group. From the resulting dendrogram, it was not possible to grade the results according to haematological parameters, but it was possible for species. Based on the multivariate analysis, carnivore and herbivore are active fishes, followed by omnivore as low active fish. From the multivariate ordination (MDS) plot (Fig. 2), it was found that all the M. cephalus was ordinated separately from all other species which confirms the dendrogram.

Haematological and biochemical parameters have been acknowledged as valuable tools for monitoring fish health, confirming maturation and monitoring any changes in the quality of water and related soil. The ranges of normal values of the key biochemical parameters are still undefined for different species in different aquaculture conditions. The results of this research provide the knowledge of the characteristics of haematological parameters of marine teleost fishes. We suggest that the haematological studies on fishes have assumed greater significance due to the increasing emphasis on pisciculture and greater awareness of the pollution in aquatic ecosystem.

Acknowledgement The authors would like to thank Dr. G. Manimehalai, HOD, Department of Zoology, Kandaswamy Kandar College, Paramathi-Velur, Tamil Nadu, India, for providing the lab facility.

\section{References}

Annino JS (1976) Clinical chemistry principles and procedures, 4th edn. Little Brown and Company, Boston

Bahmani M, Kazemi R, Donskaya P (2001) A comparative study of some hematological features in young reared sturgeons (Acipenser persicus and Huso huso). Fish Physiol Biochem 24:135140

Bano Y (1985) Sublethal stress of DDT on biochemical composition of catfish Clarias batrachus. Indian J Environ Health 27:230 236

Blaxhall PC, Daisley KW (1973) Routine haematological methods for use with fish blood. J Fish Biol 5:771-781

Borges A, Scotti LV, Siqueira DR, Jurinitz DF, Wasswemann GF (2007) Biochemical composition of seminal plasma and annual variations in semen characteristics of jundia Rhamdia quelen (Quoy and Gaimard, Pimelodidae). Fish Physiol Biochem 31:4553

Chen YE, Jin S, Wang GL (2005) Study on blood physiological and biochemical indices of Vibrio alginilyticus disease of Lateolabrax japonicas. J Ocean Tai Str 24:104-108

Clark S, Whitemore DH, Mc Mahon RF (1976) Consideration of blood parameters of largemouth bass, Micropterus salmoides. J Fish Biol 14:147-154

Cnaani A, Tinman S, Avidar Y, Ron M, Hulata G (2004) Comparative study of biochemical parameters in response to stress in $O$. aureus, O. mossambicus and two strains of $O$. niloticus. Aquaculture Res 35:1434-1440

Coz-Rakovac R, Strunjak-perovic I, Hacmanjek M, Topic PN, Lipez Z, Sostaric B (2005) Blood chemistry and histological properties of wild and cultured sea bass (Dicentrarchus labrox) in the North Adriatic Sea. Vet Res Comm 29:677-687

Dacie JV, Lewis SM (1984) Practical haematology, 6th edn. ELBS and Churchill, Livingston 
Das BC (1965) Age related trends in the blood chemistry and haematology of the Indian carp (Catla catla). Gerontologia 10:47-64

De Pedro N, Guijarro AE, Lopez-Patino MA, Marinez-Alvarez R, Delgado M (2005) Daily and seasonal variation in haematological and blood biochemical parameters in tench Tinca tinca. Aquaculture Res 36:85-96

Engel DM, Davis EM (1964) Relationship between activity and blood composition in certain marine teleosts. Copeia 3:586-587

Fawcette JK, Scott JE (1960) Practical clinical biochemistry, 4th edn. Arnold Harold Varley. pp 119-122

Folin O, Wu H (1920) Span diagnostic kits. J Biolog Chem 9:341-367

Henry RJ (1968) Clincal chemistry, principles and techniques. Harper and Row, New York, pp 664-666

Hill S (1982) A literature review of the blood chemistry of rainbow trout, Salmo gairdneri. J Fish Biol 20:535-569

Hrubec TC, Smith SA, Robertson JJ (2001) Age related in haematology and biochemistry of hybrid striped bass Chrysops morone axatilis. Vet Clin Pathol 30:8-15

Jawad LA, Al-Mukhtar MA, Ahmed HK (2004) The relationship between haematocrit and some biological parameters of the Indian shad, Tenualosa ilisha (Family Clupidae). Anim Biodivers Conserv 27:478-483

Joseph John P (2007) Alteration of certain blood parameters of fresh water teleost Mystus vittatus after chronic exposure to Metasystox and Sevin. Fish Physiol Biochem 33:15-20

Kavadias S, Castritsi-Catharios J, Dessypris A (2004) Annual cycles of growth rate, feeding rate, food conversion, plasma glucose and plasma lipids in the population of European sea bass (Dicentrarchus labrax) farmed in floating marine cages. J Appl Ichthyol 19:29-34

Lermen CL, Lappe R, Crestani M, Vieira VP, Gioda CR, Schetinger MRC, Baldisserotto B, Moraes G, Morsch VM
(2004) Effect of different temperature regimes on metabolic and blood parameters of silver catfish Rhamdia quelen. Aquaculture 239:497-507

Molnar GY (1960) Methode der Blutentnahme fur haematologische untersuchungen bei Fishcen. J Zoo and Fish 9:101-106

Ojolick EJ, Cusack R, Benfey TJ, Kerr SR (1995) Survival and growth of all female diploid and triploid Clarias macrocephalus. Fish Genetics Biotro Special Pub 52:79-86

Rambhaskar B, Srinivasa Rao K (1986) Comparative haematology of ten species of marine fish from Visakhapatnam Coast. J Fish Biol 30:59-66

Skjervold PO, Fjaera SO, Ostby PB, Einen O (2001) Live-chilling and crowding stress before slaughter of Atlantic salmon (Salmo salar). Aquaculture 192:265-280

Stillwell EJ, Benfey TJ (1995) Haemoglobin level, metabolic rate and swimming performance of triploid brook trout Salvelinus fontinalis. Aquaculture 137:355-358

Strange JR (1980) Acclimation temperature influences cortisol and glucose concentrations in stressed channel catfish. Trans Am Fish Soc 109:298-303

Strickland JDH, Parsons TR (1972) A practical hand book of seawater analysis. Fish Res Board Can, pp 310

Svobodova Z, Kroupova H, Modra H, Flajshans M, Randak T, Savina LV, Gela D (2008) Haematological profile of common carp spawners of various breeds. J App Ichthyol 24:55-59

Wintrobe MM (1974) Clinical haematology. Lea and Febiger, Philadelphia

Xiaoyun Z, Mingyun L, Khalid A, Weinmin W (2009) Comparative of haematology and serum biochemistry of cultured and wild Dojo loach Misgurnus anguillicadatus. Fish Physiol Biochem 35:43544 